\title{
The effect of Apis mellifera carnica Polm worker bee source for populating mating nuclei on degree of infection by Nosema apis Zander
}

\author{
A Gregorc 1, N Fijan 2, J Poklukar 1 \\ 1 Agricultural Institute of Slovenia, Hacquetova 2, 61109 Ljubljana, Slovenia; \\ 2 Veterinary Faculty of Zagreb, Zagreb, Republic of Croatia
}

(Received 9 December 1991; accepted 18 March 1992)

\begin{abstract}
Summary - The influence of worker bee source for populating mating nuclei on the degree of infection with Nosema apis Zander spores was examined. One-day-old bees were obtained by inserting brood combs into an incubator at $34-35^{\circ} \mathrm{C}$. Older worker bees were taken from the same donor colony. Bees from the incubator were free from Nosema infection. The average infection level in donor colonies was $26.5 \%$ infected bees. At the end of the experiments the Nosema infection level was significantly lower in mating nuclei which were populated with bees from the incubator. Out of 23 examined queens, 2 were Nosema-infected; both came from mating nuclei with young worker bees. No statistically significant difference in Nosema disease level was found between the 2 sizes of nuclei used, populated with $1 / 3$ I and $3 / 4$ I bees respectively.
\end{abstract}

Nosema disease / mating nucleus

\section{INTRODUCTION}

Nosematosis is a protozoan disease of adult honeybees, Apis mellifera $\mathrm{L}$ in which a microsporidium, Nosema apis Zander, infects the midgut epithelial cells. Colonies of honeybees which are used for commercial production, especially in queen rearing apiaries, are manipulated more often and show a higher level of infection with $N$ apis than unmanipulated colonies (Oertel, 1967; Taber and Lee, 1973). In queen rearing apiaries there are conditions favourable for causing honey- bees and young queens in the mating nuclei to become infected with $N$ apis spores (Shimanuki et al, 1973). In a normal colony, a laying queen is surrounded by healthy attendants (Wang and Moeller, 1970); thus, healthy queens can be found even in heavily infected colonies. In mating nuclei, however, the high proportion of infected bees significantly affects the risks of disease transmission, as does the fact that young queens feed themselves (Kauffeld, 1973).

To raise healthy queens, the contact of young queens with $N$ apis spores in mat- 
ing nuclei must be prevented. The present paper investigates the effect of populating the mating nuclei with young bees hatched in an incubator or with bees from a field colony on the subsequent level of infected worker bees and queens about 2 weeks after nuclei formation.

\section{MATERIAL AND METHODS}

On 10 July 1990 a group of small (Zander) and larger mating nuclei were stocked with newly emerged bees from an incubator and with young bees from bee colony. Virgin queens emerged in an incubator were added. Samples of worker bees and queens were taken 14 days later.

At the end of July and beginning of August, Zander's and a larger mating nuclei were stocked with emerged bees from an incubator and with young bees from bee colonies.

A total of 20 Zander's nuclei with 1-day-old bees and 9 with hive bees was produced. Five larger nuclei with 1 -day-old bees and 5 with hive bees were also included in the experiment.

Before use, the mating nuclei were mechanically cleaned and disinfected with chlorine $(\mathrm{Cl}$, $0.1 \%$ ). Small Zander mating nuclei (interior dimensions $12 \times 13 \times 5.5 \mathrm{~cm}$ ) were stocked with $1 / 3$ I of bees, and bigger mating nuclei $(14.5 \times$ $11 \times 16.5 \mathrm{~cm}$ ) were stocked with $3 / 4$ I of bees. Sugar honey patties were available in the nuclei throughout the experiment.

Samples of 10 worker bees were taken from each mating nucleus and 20 bees from the bee source colonies. The macerated alimentary canal of individual bees was microscopically examined at $600 \times$ and the number of spores per infected bee calculated as described by Cantwell (1970).

Queens were removed from mating nuclei and confined to Petri dishes for a few minutes to defecate. The excrements were examined microscopically and the presence or absence of $\mathrm{N}$ apis spores was determined. The statistical evaluation was based on the method of least square mean (LSQ) (Harvey, 1987).

\section{RESULTS AND DISCUSSION}

Spores of $N$ apis were not found in the 1day-old bees hatched in an incubator. This result is in agreement with Bailey's (1963) findings. In the 3 experiments, 20, 18 and $3.5 \%$ of these bees were infected after 14 , 18 and 13 days respectively. The average infection percentage was 11.2. Two possible sources of $N$ apis spores for the incubator-hatched bees were the apiary environment and the comb with the sealed brood.

The average infection level in nuclei formed from colony bees was 19.5-fold higher compared to nuclei formed from incubator-hatched bees. This difference was significant $(P<0.01)$. The smallest difference was found in August when the weather permitted intensive flight from the nuclei. At that time, when sampling for terminal infection, the average percentages of infected bees were $11.2 \pm 3.3$ and $56.4 \pm 9.6 \%$ for nuclei formed from incubator-hatched bees and from bees taken from a colony, respectively. Thus, establishing mating nuclei with bees hatched in an incubator significantly reduces the percentage of Nosema-infected bees $(P<0.01)$. These results are in agreement with data presented by Loskotova et al (1980). Of the 23 queens examined, 2 were found positive for $N$ apis spores (table I). Unexpectedly, both these queens were from nuclei stocked with 1day-old bees. Thus, our results also indicate that of infected bees in a nuclei, young queens easily become infected, irrespective of the source of bees.

The acceptance of virgin queens amounted to $84 \%$ in the nuclei with newly emerged bees and $50 \%$ in the nuclei with bees from a colony. The influence of Nosema-infected worker bees in nuclei on virgin queen acceptance was not determined. 
Table I. $N$ apis infection level in nuclei established from 1-day-old incubator-hatched bees or from bees collected from a bee colony.

\begin{tabular}{|c|c|c|c|c|c|c|c|}
\hline $\begin{array}{l}\text { Bee } \\
\text { source }\end{array}$ & $\mathbf{N}$ & $\begin{array}{l}\text { Initial } \\
\text { infection }\end{array}$ & $\begin{array}{l}\text { Initial } \\
\text { infection (\%) }\end{array}$ & $\begin{array}{l}\text { Terminal } \\
\text { infection }\end{array}$ & $\begin{array}{l}\text { Terminal } \\
\text { infection (\%) }\end{array}$ & $\begin{array}{l}\text { Exam } \\
\text { queens }\end{array}$ & Inf \\
\hline $\begin{array}{l}\text { Incub } \\
\text { Colony }\end{array}$ & $\begin{array}{l}25 \\
14\end{array}$ & $\begin{array}{l}0 \\
0.9 \pm 0.4\end{array}$ & $\begin{array}{c}0 \\
20.4 \pm 3.6\end{array}$ & $\begin{array}{r}0.7 \pm 0.6 \\
14.0 \pm 4.4\end{array}$ & $\begin{array}{l}11.2 \pm 3.3 \\
56.4 \pm 9.6\end{array}$ & $\begin{array}{r}16 \\
7\end{array}$ & $\begin{array}{l}2 \\
0\end{array}$ \\
\hline
\end{tabular}

Source of bees, number of nuclei $(M)$, average initial spore count $\times 10^{5}(x \pm S E)$, average initial percentage of infected bees, average source count $\times 10^{5} 13-18$ days after nuclei formation (terminal infection, $x \pm S E$ ), average percentage of infected bees 13-18 days after nuclei formation (percentage of terminal infection, $x \pm S E$ ), number of examined queens, number of infected queens. Incub = incubator.

The effect of nuclei size or the quantity of stocking bees on the percentage of Nosema-infected worker bees or queens was not statistically significant $(P>0.05)$.

\section{Résumé. - Influence de l'origine des ouvrières d'abeilles (Apis mellifera car- nica Polm) constituant les nuclei de fé- condation sur le taux d'infection par No- sema apis Zander. On a étudié l'influence} de l'origine des ouvrières d'abeilles utilisées pour former des nuclei de fécondation sur le degré d'infection par les spores de Nosema apis Zander. Des ouvrières âgées d'un jour ont été obtenues en plaçant des rayons de couvain dans une étuve à $34-35{ }^{\circ} \mathrm{C}$. Des ouvrières plus âgées ont été prélevées dans la même colonie donneuse. Les abeilles venant de l'étuve étaient indemnes de nosémose. Le taux moyen d'infection dans les colonies donneuses a été de $26,5 \%$. À la fin de l'expérience, le niveau de nosémose était significativement plus bas dans les nuclei de fécondation qui avaient été peuplées avec des ouvrières provenant de l'étuve. Sur 23 reines examinées, 2 étaient atteintes de nosémose; curieusement elles provenaient toutes 2 de nuclei peuplés d'ouvrières d'un jour. On n'a trouvé aucune différence sta- tistiquement significative dans le niveau de nosémose entre les nuclei peuplés avec 1/ 3 I d'abeilles et ceux peuplés avec $3 / 4$ I.

nucleus de fécondation / nosémose

\section{Zusammenfassung. - Nosemainfektion von Begattungsvölkchen und die Her- kunft der Arbeitsbienen (Apis mellifera carnica Polm) bei ihrer Bildung. Es} wurde der Einfluß der Herkunft der Arbeiterbienen für die Bildung von Begattungsvölkchen auf den Infektionsgrad mit Sporen von Nosema apis Zander untersucht. Eintägige Arbeiterinnen wurden durch Einstellen von Brutwaben in einen Brutschrank bei $34-35{ }^{\circ} \mathrm{C}$ gewonnen. Ältere Arbeiterinnen wurden aus demselben Spendervolk genommen. Die Bienen aus dem Brutschrank waren frei von Nosemainfektion. Der mittlere Infektionsgrad der Spendervölker war $26.5 \%$ infizierte Bienen. Am Ende des Versuchs war der Befallsgrad der Begattungsvölkchen, die aus Brutschrankbienen gebildet worden waren, signifikant niedriger. Von 23 untersuchten Königinnen waren zwei Nosemabefallen; beide stammten aus Völkchen aus eintägigen Arbeiterinnen. Zwischen Begattungsvölkchen, die aus 1/3 Liter und 
aus 3/4 Liter Bienen gebildet worden waren, bestand kein signifikanter Unterschied im Grad des Nosemabefalls.

\section{Begattungsvölkchen / Nosema}

\section{REFERENCES}

Bailey L (1963) Infectious Diseases of the Honey Bee. Land Books Ltd, London

Cantwell GE (1970) Standard methods for counting Nosema spores. Am Bee J 110, 222-223

Harvey WR (1987) User's Guide to LSMLMW. Mixed Model Least-Squares and Maximum Likehood Computer Program. Ohio State Univ, $\mathrm{OH}$
Kuffeld NM (1973) Queen honey bees in colonies: susceptibility to Nosema disease. Am Bee J 113, 12-14

Loskotova J, Peroutka M, Vesely V (1980) Nosema disease of honeybee queens (Apis mellifica L). Apidologie 11, 153-161

Oertel E (1967) Colony disturbance and Nosema disease. J Apic Res 6, 119-120

Shimanuki H, Lehnert T, Knox D (1973) Transmission of Nosema disease from infected honey bee workers to queens in mating nuclei. J Econ Entomol 66, 777-7.78

Taber S, Lee H (1973) Seasonal variations in levels of Nosema infection in honey bees in Arizona. Am Bee J 113, 281-282

Wang I, Moeller FE (1970) The division of labor and queen attendance behavior of Nosemainfected worker honey bees. J Econ Entomol $63,1539-1541$ 